\title{
Cell of Origin and Immunologic Events in the Pathogenesis of Breast Implant-Associated Anaplastic Large-Cell Lymphoma
}

\author{
Suzanne D. Turner, ${ }^{*}$ Giorgio Inghirami, ${ }^{\dagger}$ Roberto N. Miranda, ${ }^{\ddagger}$ and Marshall E. Kadin ${ }^{\S \Phi}$
}

From the Division of Cellular and Molecular Pathology, * Department of Pathology, University of Cambridge, Cambridge, United Kingdom; the Department of Pathology and Laboratory Medicine, ${ }^{\dagger}$ Weill Cornell Medicine, New York, New York; the Department of Hematopathology, ${ }^{\ddagger}$ The University of Texas MD Anderson Cancer Center, Houston, Texas; and the Department of Dermatology, ${ }^{\S}$ Roger Williams Medical Center, Providence, Rhode Island; and the Department of Dermatology, ${ }^{\circledR}$ Boston University School of Medicine, Boston, Massachusetts

Accepted for publication September 17, 2019.

Address correspondence to Suzanne D. Turner, Ph.D., Division of Cellular and Molecular Pathology, Department of Pathology, University of Cambridge, Lab Block Level 3, Box 231, Addenbrooke's Hospital, Cambridge CB20QQ, United Kingdom. E-mail: sdt36@cam. ac.uk.

\begin{abstract}
Breast implant-associated anaplastic large-cell lymphoma (BIA-ALCL) is a CD30-positive, anaplastic lymphoma kinase-negative T-cell lymphoma. Nearly all cases have been associated with textured implants. Most cases are of effusion-limited, indolent disease, with an excellent prognosis after implant and capsule removal. However, capsular invasion and tumor mass have a more aggressive course and a fatal outcome risk. This review summarizes the current knowledge on BIA-ALCL cell of origin and immunologic factors underlying its pathogenesis. Cytokine expression profiling of BIA-ALCL cell lines and clinical specimens reveals a predominantly type 17 helper T-cell (Th17)/Th1 signature, implicating this as its cell of origin. However, a Th2 allergic inflammatory response is suggested by the presence of IL-13, with infiltration of eosinophils and IgE-coated mast cells in clinical specimens of BIA-ALCL. The microenvironment-induced T-cell plasticity, a factor increasingly appreciated, may partially explain these divergent results. Mutations resulting in constitutive Janus kinase (JAK)-STAT activation have been detected and associated with BIA-ALCL pathogenesis in a small number of cases. One possible scenario is that an inflammatory microenvironment stimulates an immune response, followed by polyclonal expansion of Th17/Th1 cell subsets with release of inflammatory cytokines and chemokines and accumulation of seroma. JAK-STAT3 gain-of-function mutations within this pathway and others may subsequently lead to monoclonal T-cell proliferation and clinical BIA-ALCL. Current research suggests that therapies targeting JAK proteins warrant investigation in BIA-ALCL. (Am J Pathol 2020, 190: 2-10; https://doi.org/10.1016/j.ajpath.2019.09.005)
\end{abstract}

In 1997, a case of CD30-positive, anaplastic lymphoma kinase (ALK)-negative T-cell lymphoma in proximity to a breast implant was first reported. ${ }^{1}$ Other cases of this uncommon malignancy (estimated US incidence, 2.03 per million person-years for textured implants) ${ }^{2}$ were subsequently reported, with nearly all confirmed cases either associated with textured (versus smooth) implants or occurring in patients who had previously had textured implants. $^{2-4}$ In 2016, the World Health Organization recognized breast implant-associated anaplastic large-cell lymphoma (BIA-ALCL) as a provisional entity distinguished from other ALK-negative ALCLs. ${ }^{5}$ Similar numbers of BIA-ALCL cases have been reported among patients with implants for breast reconstruction for breast cancer or prophylaxis and for cosmetic purposes. ${ }^{2-4,6}$ Most patients with BIA-ALCL present with seroma without capsular invasion. ${ }^{3,6,7}$ Time of seroma occurrence after initial implantation or reimplantation ranges from 0.2 to 27 years in retrospective studies. ${ }^{6,8}$ In these cases, BIA-ALCL follows an indolent course, with patients having a favorable

Supported by Allergan plc, Dublin, Ireland.

Disclosures: M.E.K., G.I., and R.N.M. have served on scientific advisory boards on breast implant-associated anaplastic large-cell lymphoma (BIAALCL) for Allergan; S.D.T. has served on scientific advisory boards on BIA-ALCL for Allergan without remuneration. 
prognosis after complete surgical excision. ${ }^{9}$ However, patients with tumor mass infiltration of capsule and adjoining tissue face a more aggressive disease. ${ }^{9-11}$ The spectrum of cytologic and histologic changes encountered in BIA-ALCL is illustrated in Figure 1. The purpose of this review is to summarize what is known about the BIA-ALCL cell of origin and immunologic factors underlying the pathogenesis of BIA-ALCL and to identify key areas where we believe future research is needed.

\section{Triggering Event}

Much of the underlying etiology of BIA-ALCL remains to be elucidated, but multiple factors appear to be involved in its development, including host genetic factors. ${ }^{7,12}$ Various triggers, with varying degrees of evidence, have been proposed for the development of BIA-ALCL, including mechanical friction, implant shell particulates, implant components leaching into surrounding tissue, and bacterial biofilm. ${ }^{13,14}$ The evidence supporting the association of bacterial biofilm with a greater risk of BIA-ALCL is that the uneven surfaces of textured breast implants provide a sheltered environment for bacterial proliferation, supporting a higher biofilm load than is possible for smooth implants and explaining the higher rates of BIA-ALCL with textured implants. ${ }^{6,15}$ Another possibility for triggering a pathophysiological cascade is that a superantigen may be involved, as is the case in cutaneous T-cell lymphoma, ${ }^{16}$ although this remains speculative for BIA-ALCL at present. The discovery of ribosomal protein S10 in BIA-ALCL samples suggests that viral etiology is another possibility because ribosomal protein S10 contributes to formation of the internal ribosome entry site by which viral transcripts gain entry to the ribosome. ${ }^{17,18}$

\section{Innate Immune Response}

Cellular and cytokine studies suggest that an inflammatory milieu may be a necessary component of the pathobiology of BIA-ALCL. ${ }^{19-21}$ In response to bacteria or other yet undefined antigens, acute inflammation is initiated by innate immune cells (eg, mast cells, neutrophils, and macrophages). ${ }^{22}$ Through antigen presentation, these cells may activate adaptive immune cell responses via the release of cytokines and chemokines. ${ }^{23}$

The lymphoma cells of most cases of BIA-ALCL lack T-cell receptors $\alpha / \beta$ or $\gamma / \delta$ or have gene mutations that may contribute to a defective T-cell receptor phenotype. ${ }^{1,21,24-27}$ Lack of adaptive T-cell functionality suggests that an innate immune response may significantly contribute to BIA-ALCL immunopathophysiology. This may be further supported by a study using human peripheral blood mononuclear cell cultures, which found that exposure to silicone breast implant surfaces did not induce T-cell activation. However, some implant surfaces resulted in increased expression of the proinflammatory cytokines IL-1 $\beta$, IL-6, and tumor necrosis factor- $\alpha$, which play a role in macrophage activation. ${ }^{28}$ Furthermore, eosinophils and mast cells with strongly bound cell-surface IgE, which are characteristic of allergic inflammation, have been found in BIA-ALCL tissue ${ }^{20}$ (Figure 2).

IL-22, produced by group 3 innate lymphoid cells (ILC3), has been associated with malignancies, including T-cell lymphomas. ${ }^{29,30}$ Up-regulation of ILC3 genes and secretion of IL-22 have been observed in ALCL cell lines,
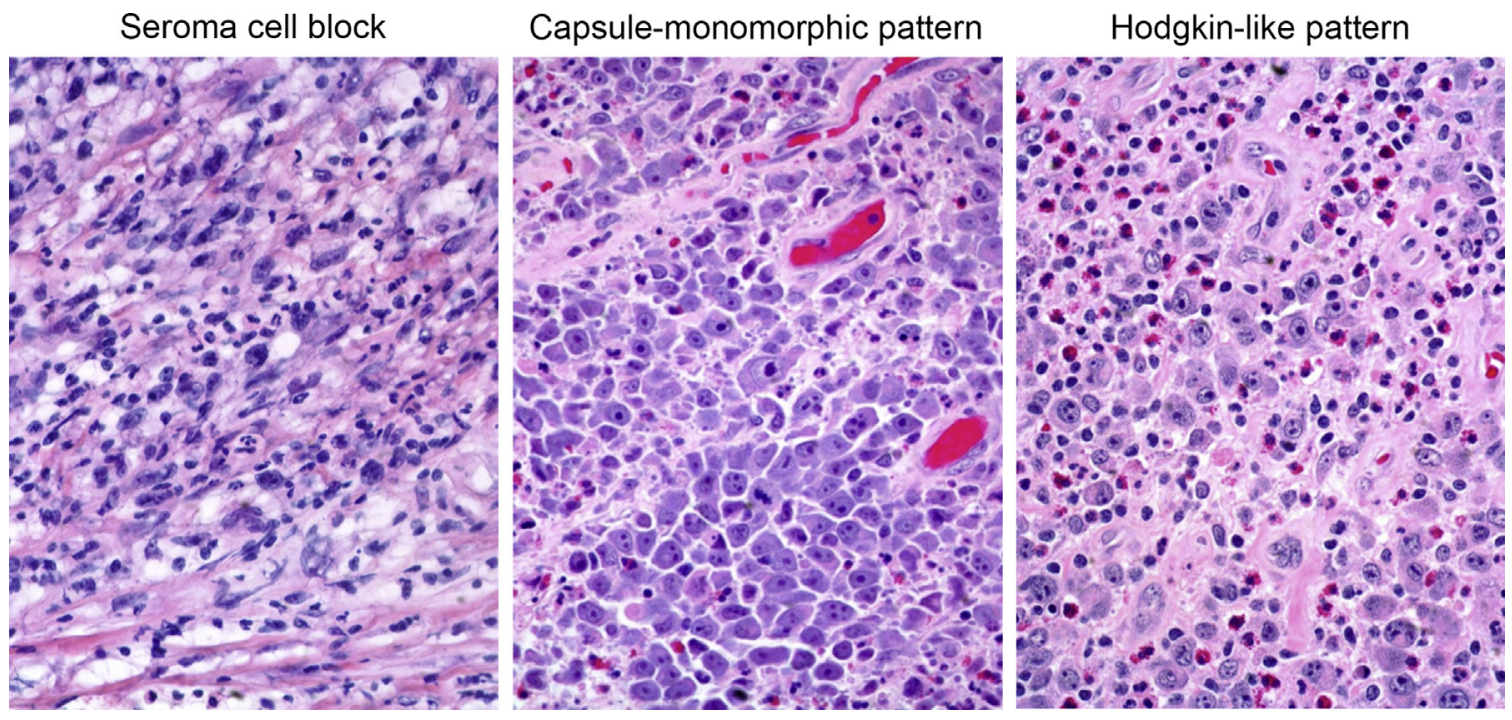

Figure 1 Spectrum of cytologic and histologic changes in breast implant-associated anaplastic large-cell lymphoma (BIA-ALCL). Left panel: The seroma cell block contains large anaplastic cells with an admixture of inflammatory cells and fibrin. Seroma cell blocks are helpful for the diagnosis of BIA-ALCL. Middle and right panels: The spectrum of morphologic changes that can be encountered when BIA-ALCL infiltrates the capsule and surrounding breast tissue. Original magnification, $\times 400$. 
Mast cells coated with IgE in BIA-ALCL

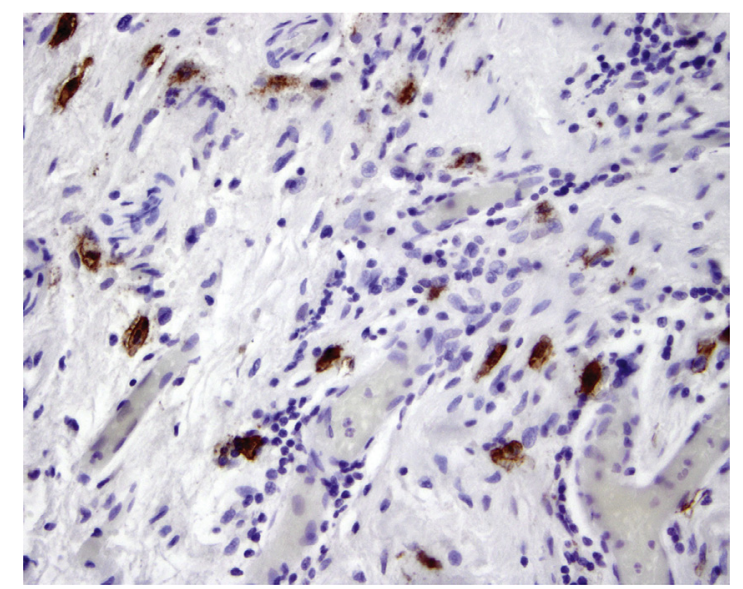

Figure 2 Mast cells in breast implant-associated anaplastic large-cell lymphoma (BIA-ALCL) show strong IgE surface expression (brown stain). Rabbit antibody (catalog number 75673; Abcam, Cambridge, UK) was used neat. Second-stage antibody was from R\&D Systems (Minneapolis, MN; catalog number (TS005). Original magnification, $\times 400$.

pointing to ILC3 cells as a potential cell of origin for ALK-positive ALCLs. ${ }^{31}$

\section{Cell of Origin}

Thymic Progenitor Cells in ALCL

Because of the relatively recent recognition of BIA-ALCL as a clinical entity and its relative rarity, knowledge of its pathobiology is more limited than for the other types of ALCL, such as systemic ALK-positive ALCL (ALK-positive sALCL), systemic ALK-negative ALCL (ALK-negative sALCL), and primary cutaneous ALCL (pcALCL). ${ }^{32}$ Although ALCL subtypes are associated with divergent clinical presentations and prognoses, some aspects of their pathogenesis are shared. ${ }^{33}$ All ALCL subtypes have common features, including variable expression of surface markers that support a T-cell origin. All are positive for CD30, which is a cell membrane protein of the tumor necrosis factor receptor family normally found on the surface of activated B and T cells. ${ }^{11,26,34-36}$ In addition, T-cell receptor gene rearrangements are seen and there is rare cell surface T-cell receptor expression and the frequent loss of CD3. ${ }^{11,21,26,27,35,37-39}$ All studied subtypes have anaplastic morphology ${ }^{40}$ and strongly express antigen presentation-associated proteins (human leukocyte antigen$\left.\mathrm{DR}^{+} \mathrm{CD} 80^{+} \mathrm{CD} 86^{+}\right){ }^{21,35,41}$ Malignant cells are commonly CD4 positive, less frequently CD8 positive, and rarely CD4/ CD8 double positive. ${ }^{11,26,27,35,42,43}$ Some cases are CD4\% $\mathrm{CD}^{-} / \mathrm{CD}^{-}$(triple negative; null cell phenotype), but are still T-cell derived, as evidenced by molecular T-cell receptor rearrangements. ${ }^{11,26,27,35,42,44}$ Nonetheless, ALCL often expresses perforin and/or granzyme $\mathrm{B}$, irrespective of CD4/CD8 phenotype. ${ }^{11,26,42,43,45-47}$ BIA-ALCL has similarities with pcALCL in terms of morphology, biomarkers, a typically localized disease with frequent absence of systemic symptoms, and a generally favorable prognosis. ${ }^{9,48}$

Assigning a cell of origin to any ALCL has proved challenging, although all ALCLs fall under the umbrella of peripheral T-cell lymphomas and, thus, by definition, are of post-thymic origin. In one study, gene expression profiling (GEP) of a subpopulation of ALK-positive and ALKnegative ALCL cells reflected an early thymic progenitor origin. ${ }^{49}$ Yet, in another study of ALK-positive ALCL, ALK-negative ALCL, and pcALCL, GEP was unable to clearly assign a pattern of $\mathrm{CD}^{+}$helper $\mathrm{T}$ cell, $\mathrm{CD} 8^{+}$ cytotoxic $\mathrm{T}$ cell, or $\mathrm{CD} 30^{+}$activated $\mathrm{T}$ cell of origin to ALCLs. ${ }^{50}$ However, in this study, the GEP of subsets of helper and cytotoxic $\mathrm{T}$ cells was not considered. In the case of ALK-positive sALCL, in vivo studies have provided evidence of an early thymocyte origin with T-cell receptor expression, which is necessary for thymic egress. ${ }^{39}$ In addition, DNA methylation fingerprints in both ALKpositive and ALK-negative ALCL samples were found to be consistent with a thymic origin, although epigenomic reprogramming at a later stage could not be ruled out. ${ }^{51}$

\section{Th17/Th1 Phenotype}

A different cell of origin was recently suggested by a GEP study of several ALK-positive and ALK-negative cell lines. ${ }^{31}$ These cells demonstrated a GEP characteristic of type 17 helper T cells (Th17) and, in some cases, ILC3 cells, with AP-1-BATF and AP-1-BATF3 playing a crucial role in Th17/ILC3 skewing. ${ }^{31,52}$ Further supporting a Th17 phenotype, the IL-17A and IL-17F cytokines were secreted by these cells and were detectable in patients with ALCL. These findings were consistent with a previous study in which IL-17A and IL-17F were shown to be associated with ALCL. ${ }^{52}$ Although these studies did not include BIAALCL, the origin of these ALCL subtypes is of more than academic interest because eradication of clinical disease depends on elimination of any reservoirs that might cause relapse. $^{53}$

In considering cellular origin and phenotype, $\mathrm{CD} 4^{+}$ helper T-cell plasticity must be kept in mind. ${ }^{54}$ Differentiation of naïve $\mathrm{CD} 4^{+} \mathrm{T}$ cells into discrete Th1, Th2, Th17, regulatory $\mathrm{T}$ cells, and other subsets is not only context dependent, but the polarization states reached in some cases maintain context-dependent late plasticity governed by epigenetic regulation that is, in turn, influenced by secondary stimulation. ${ }^{55}$ Specifically, Th17 cells are known to be capable of acquiring functional characteristics associated with Th1 cells, although the reverse does not seem to occur, ${ }^{56}$ and cells producing both IL-17A and interferon- $\gamma$ have been reported. Thus, Th17 cells recruited in response to extracellular antigens may initiate an inflammatory response via IL-17A and IL-17F before transitioning into 
A

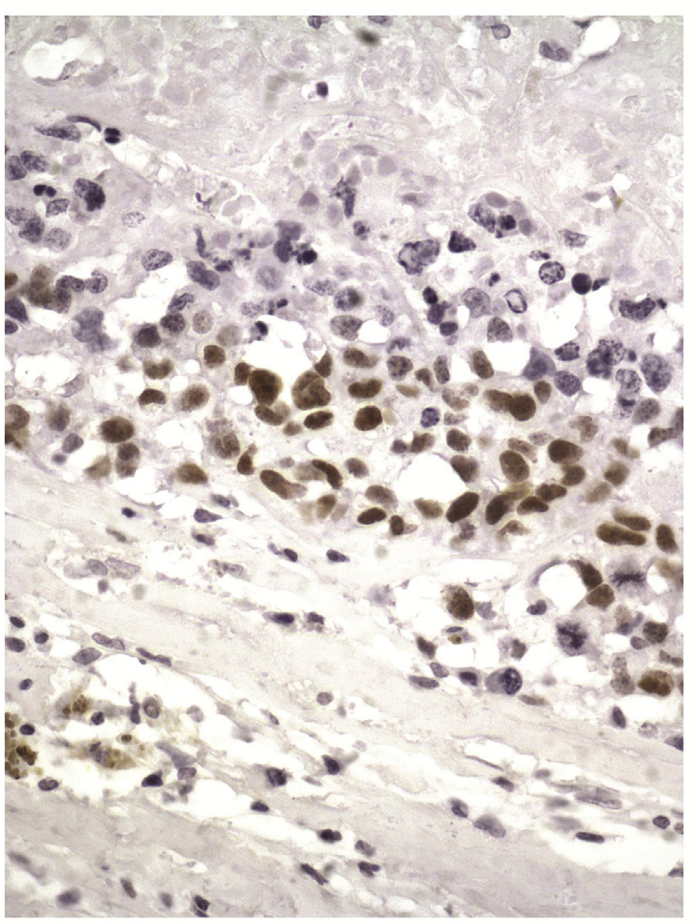

B

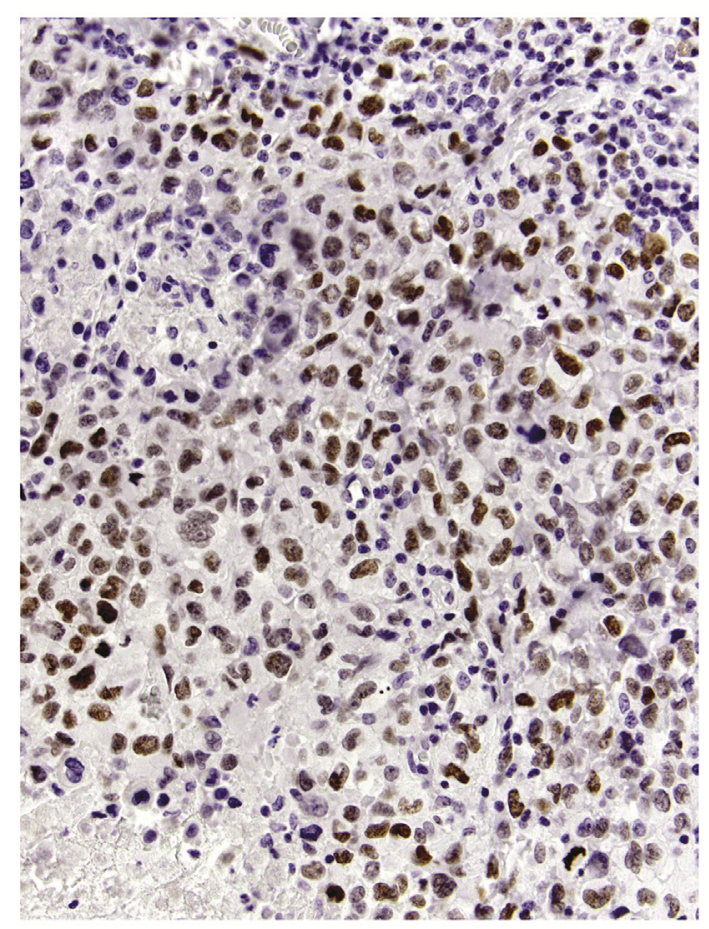

Figure 3 A: Anaplastic cells in breast implant-associated anaplastic large-cell lymphoma (BIA-ALCL) express Janus kinase 1 (JAK1; nucleus, brown stain). Rabbit monoclonal antibody (mAb) IgG number 3344 (Cell Signaling Technology, Danvers, MA) was used at 1:100 dilution. B: Anaplastic BIA-ALCL cells express phospho-STAT3 (pSTAT3) in the nucleus (brown stain). (Tyr705)(D3A7) rabbit mAb IgG number 9145 (Cell Signaling Technology) was used at 1:200 dilution. Original magnification: $\times 600(A)$; $\times 400$ (B).
Th1-like cells, thereby providing characteristics of both cell types. ${ }^{55}$

A study of BIA-ALCL GEP was performed on cell lines derived from patient samples as well as pcALCL cell lines. ${ }^{48}$ BIA-ALCL cells displayed moderate to high expression levels of the Th1 signature cytokine interferon- $\gamma$ as well as IL-17A and IL-17F. Interestingly, high expression of suppressor of cytokine signaling 3, which has been proposed to play a role in ALCL pathogenesis via the Janus kinase 3-signal transducer and activator of transcription 3 (JAK3-STAT3) pathway, ${ }^{57}$ was also characteristic of BIAALCL cells. BIA-ALCL cells and pcALCL cells had similar cytokine and transcription factor profiles, including high levels of suppressor of cytokine signaling 3, SATB1, and JunB, which may promote lymphoma development through transcriptional regulation of platelet-derived growth factor receptor- $\beta$. $^{48,58,59}$ Expression of IL-17F and interferon- $\gamma$ was confirmed in BIA-ALCL tumor cells and surrounding capsule from clinical samples, with stronger IL-17F expression in capsular infiltrates. ${ }^{48}$

Collectively, these results suggest that breast implants may, by still undefined mechanisms, trigger a local Th17/ Th1 immune response, leading to subsequent cytokinepromoted fibrosis and the formation of the peri-implant capsule. ${ }^{48}$ Given the extremely low incidence rate of BIAALCL, in the vast majority of cases, this must not have downstream malignant sequelae, although it may be a factor in the capsular contracture sometimes encountered. Accepting the hypothesis of a predominantly Th17/Th1 phenotype, what then remains to be elucidated are the additional hits and downstream transformational processes necessary for the development of BIA-ALCL in this milieu.

\section{Immunologic Pathways in BIA-ALCL Pathogenesis}

\section{The Role of Inflammation}

Several lines of evidence point to the role of an inflammatory environment with chronic T-cell stimulation in BIAALCL pathogenesis. In clinical specimens from patients with BIA-ALCL that was invasive through the peri-implant capsule, malignant cells were associated with an inflammatory background with a large number of eosinophils (Figure 1). ${ }^{11}$ BIA-ALCL cell lines and 14 of 14 clinical BIA-ALCL capsule specimens were found to secrete or express IL-13, the Th2-associated signature cytokine of allergic inflammation, which was only infrequently expressed in ALK-negative sALCL, ALK-positive sALCL, ${ }^{60}$ or benign capsular tissue specimens. ${ }^{20}$ In this study, BIA-ALCL tissue samples contained numerous eosinophils and mast cells with surface-expressed IgE, also characteristic of allergic inflammation. In contrast, few ALK-negative or ALK-positive sALCL samples contained eosinophils, and ALK-positive ALCL has been associated with predominantly Th17 cytokines. ${ }^{61}$ These results suggest 


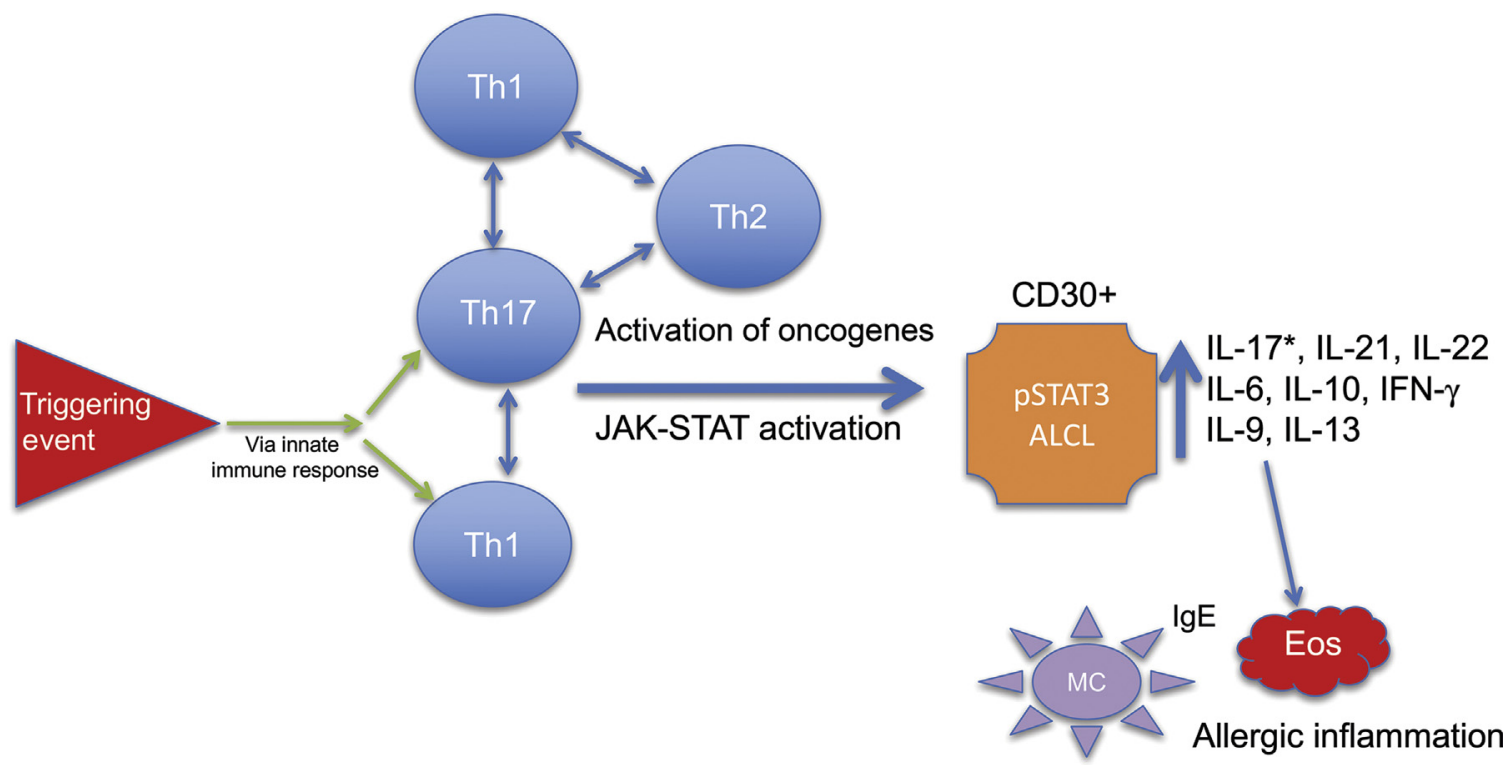

Figure 4 Proposed hypothesis for progression of immune T-cell infiltrates to breast implant-associated anaplastic large-cell lymphoma (BIA-ALCL). In this proposed model, a triggering event elicits both innate and adaptive [type 17 helper T-cell (Th17)/Th1/Th2] immune responses. Oncogenic events, including critical mutations leading to constitutive Janus kinase (JAK)-STAT activation and/or other oncogenic drivers, result in the emergence of monoclonal, CD30positive BIA-ALCL cells capable of amplifying the inflammatory environment through plasticity and secretion of cytokines, leading to infiltration of eosinophils (Eos) and IgE-coated mast cells (MC). *Variable reports of IL-17 expression in the literature. IFN- $\gamma$, interferon- $\gamma$; pSTAT3, phospho-STAT3.

that IL-13 is a functional biomarker of BIA-ALCL and imply that allergic inflammation may be a unique component of its pathogenesis. Furthermore, allergen-bound $\operatorname{IgE}$ causes mast cell activation, resulting in the release of cytokines, such as IL-9, IL-13, and the inflammatory mediator histamine, and chemokines, including prostaglandin D2. ${ }^{62-64}$ Histamine, in turn, promotes microvascular permeability; its release from mast cells may contribute to the pathogenesis of BIA-ALCL. ${ }^{65}$

The presence of numerous eosinophils is also characteristic of most Hodgkin lymphomas. ${ }^{66}$ It was found that these express functionally active CD30 ligand on their surfaces, which acts to transduce proliferative signaling in $\mathrm{CD} 0^{+}$cells, including Reed-Sternberg cells, thereby representing an important element in Hodgkin lymphoma pathology. ${ }^{66}$ In a subsequent investigation, multivariate analysis revealed that eosinophilia was the strongest prognostic factor in nodular sclerosing Hodgkin lymphoma, predicting poor outcomes for freedom from treatment failure $(P<0.001)$ and overall survival $(P<0.001)$ in a stagestratified model. ${ }^{67}$ Although CD30 ligand is known to be expressed in several B- and T-cell malignancies, ${ }^{68}$ its expression and potential role in BIA-ALCL, although intriguing, remain to be elucidated.

The apparent divergence with the IL-17F- and interferon- $\gamma$-producing Th17/Th1 phenotype that evidence suggests comprises the cell of origin may be explained, in part, by several factors. In a chronically inflamed milieu, subsets of Th2 cells would be expected to be present. The known plasticity of helper T-cell subtypes could also factor into this difference. Multiple subtypes, including regulatory
$\mathrm{T}$ cells, appear to be capable of differentiation into Th17-producing cells. ${ }^{69}$ In addition, CD30-mediated IL-13 production from $\mathrm{CD}^{+} \mathrm{T}$ cells that is entirely independent of T-cell receptor signaling has been reported in a murine model. ${ }^{70}$ Thus, it is conceivable that neoplastic BIA-ALCL cells, which, as previously noted (Innate Immune Response), generally lack surface T-cell receptor expression, may still serve as a source of this inflammatory cytokine.

\section{JAK-STAT Pathway Centrality}

Cytokine signaling predominantly uses the JAK-STAT pathway, which is, therefore, central in converting extracellular signals into changes in cellular protein expression. ${ }^{71}$ Acquired mutations in JAK-STAT signaling have been associated with oncogenesis in T-cell lymphomas. ${ }^{72,73}$ JAKl and/or STAT3 mutations were found in $37.5 \%$ of ALK-negative sALCL specimens; fusion proteins involving the kinases TYK2 and ROS1, leading to constitutive STAT activation, were also identified, implicating STAT3 activation as a key oncogenic driver in this cancer type. ${ }^{12,74,75}$

A study of whole exome sequencing on DNA extracted from effusion cytology fluid and germline DNA of two patients with effusion-limited BIA-ALCL revealed somatic, activating mutations in JAK1 and STAT3 as well as a germline JAK3 mutation, the latter suggesting a possible genetic risk factor for the development of this lymphoma. ${ }^{12}$ Clinical specimens from 12 of 12 patients with BIA-ALCL tested positive for phospho-STAT3 (pSTAT3) by immunohistochemistry. ${ }^{11}$ Examination of capsular tissue from patients with BIA-ALCL by 
immunohistochemistry found that all tested cases $(n=27)$ were positive for the presence of activated STAT3, which is found in only $38 \%$ to $47 \%$ of ALKnegative ALCLs $^{76}$ (Figure 3). BIA-ALCL cell lines expressed high levels of p-STAT3, which correlated with aggressiveness in xenografted mice. ${ }^{21}$ These cell lines also produce high levels of the cytokines IL-6 and IL-10, both of which transduce signals via STAT3; and investigators have proposed that autocrine signaling by IL-6 is necessary for survival of these cells. ${ }^{21,77,78}$ Two of the three BIA-ALCL cell lines tested (both having activating STAT3 mutations) and most of other ALK-negative cell lines exhibited absolute JAK1-STAT3 dependence; in these cell lines, the JAK inhibitors ruxolitinib, tofacitinib, and AZ-3 as well as JAK1 and STAT3 knockdown by shRNA inhibited proliferation. ${ }^{79}$ Cells that were $\mathrm{p}$ STAT3 positive were susceptible to JAK inhibition regardless of the presence of JAK-STAT mutations, which implies that other mechanisms resulting in constitutive p-STAT3 expression are operative but that these cells still depend on JAK1-STAT3 signaling. ${ }^{79}$

These findings have several noteworthy implications. Dysregulation of JAK-STAT signaling appears to play a central role in the development of BIA-ALCL. From a therapeutic standpoint, JAK-STAT dependence may, therefore, constitute an attractive target in BIA-ALCL, and could represent an additional targeted approach, with case studies currently reporting efficacy for the anti-CD30 antibody-drug conjugate brentuximab vedotin. ${ }^{80,81}$

\section{Conclusions}

The existing data suggest that BIA-ALCL is a complex disease resulting from the interplay of several pathophysiological processes. It is likely that a triggering event stimulates an immune response, leading to the recruitment of lymphocytes and other inflammatory cells (Figure 4). However, much remains to be understood regarding its etiology and the mechanisms driving its progression, necessitating further investigation. The proposed role of bacterial biofilms and other possible triggers of the inflammatory immune cascade requires further studies. The presence of both a distinctly inflammatory phenotype with a Th17/Th1 cell of origin and a distinct Th2 phenotype characteristic of allergic inflammation must be reconciled, and it will need to be determined if this duality reflects Tcell plasticity and/or a downstream effect of Th17/Th1 inflammation. In addition, a thorough assessment of the impact of JAK-STAT pathway mutations may give additional insight into the mechanisms of disease, as well as direct therapeutic strategies for its management. Ongoing and future research on the molecular mechanisms underlying BIA-ALCL may provide still better options for its prevention and treatment in all patients.

\section{Acknowledgments}

We thank Robert Rydzewski, M.S., C.M.P.P. (Peloton Advantage, LLC, Parsippany, NJ) for providing writing and editorial assistance (funded by Allergan plc, Dublin, Ireland).

\section{Author Contributions}

M.E.K. co-authored the manuscript, provided illustrations, and introduced concepts of pathogenesis of breast implant-associated anaplastic large-cell lymphoma; S.D.T. developed concepts discussed in the manuscript and coauthored and edited the manuscript; all authors approved the manuscript.

\section{References}

1. Keech JA Jr, Creech BJ: Anaplastic T-cell lymphoma in proximity to a saline-filled breast implant. Plast Reconstr Surg 1997, 100:554-555

2. Doren EL, Miranda RN, Selber JC, Garvey PB, Liu J, Medeiros LJ, Butler CE, Clemens MW: United States epidemiology of breast implant-associated anaplastic large cell lymphoma. Plast Reconstr Surg 2017, 139:1042-1050

3. Campanale A, Boldrini R, Marletta M: 22 Cases of breast implantassociated ALCL: awareness and outcome tracking from the Italian Ministry of Health. Plast Reconstr Surg 2018, 141:11e-19e

4. de Boer M, van Leeuwen FE, Hauptmann M, Overbeek LIH, de Boer JP, Hijmering NJ, Sernee A, Klazen CAH, Lobbes MBI, van der Hulst R, Rakhorst HA, de Jong D: Breast implants and the risk of anaplastic largecell lymphoma in the breast. JAMA Oncol 2018, 4:335-341

5. Swerdlow SH, Campo E, Pileri SA, Harris NL, Stein H, Siebert R, Advani R, Ghielmini M, Salles GA, Zelenetz AD, Jaffe ES: The 2016 revision of the World Health Organization classification of lymphoid neoplasms. Blood 2016, 127:2375-2390

6. Loch-Wilkinson A, Beath K, Knight RJW, Wessels WLF, Magnusson M, Papadopoulos T, Connell T, Lofts J, Locke M, Hopper I, Cooter R, Vickery K, Joshi PA, Prince HM, Deva AK: Breast implant associated anaplastic large cell lymphoma in Australia and New Zealand: high surface area textured implants are associated with increased risk. Plast Reconstr Surg 2017, 140:645-654

7. Leberfinger AN, Behar BJ, Williams NC, Rakszawski KL, Potochny JD, Mackay DR, Ravnic DJ: Breast implant-associated anaplastic large cell lymphoma: a systematic review. JAMA Surg 2017, 152:1161-1168

8. Srinivasa DR, Miranda RN, Kaura A, Francis AM, Campanale A, Boldrini R, Alexander J, Deva A, Gravina P, Medeiros LJ, Nast K, Butler CE, Clemens MW: Global adverse event reports of breast implant-associated ALCL: an international review of 40 government authority databases. Plast Reconstr Surg 2017, 139:1029-1039

9. Clemens MW, Medeiros LJ, Butler CE, Hunt KK, Fanale MA, Horwitz S, Weisenburger DD, Liu J, Morgan EA, KanagalShamanna R, Parkash V, Ning J, Sohani AR, Ferry JA, Mehta-Shah N, Dogan A, Liu H, Thormann N, Di Napoli A, Lade S, Piccolini J, Reyes R, Williams T, McCarthy CM, Hanson SE, Nastoupil LJ, Gaur R, Oki Y, Young KH, Miranda RN: Complete surgical excision is essential for the management of patients with breast implant-associated anaplastic large-cell lymphoma. J Clin Oncol 2016, 34:160-168

10. Miranda RN, Aladily TN, Prince HM, Kanagal-Shamanna R, de Jong D, Fayad LE, Amin MB, Haideri N, Bhagat G, Brooks GS, Shifrin DA, O'Malley DP, Cheah CY, Bacchi CE, Gualco G, Li S, Keech JA Jr, Hochberg EP, Carty MJ, Hanson SE, Mustafa E, Sanchez S, Manning JT Jr, Xu-Monette ZY, Miranda AR, Fox P, Bassett RL, Castillo JJ, Beltran BE, de Boer JP, Chakhachiro Z, 
Ye D, Clark D, Young KH, Medeiros LJ: Breast implant-associated anaplastic large-cell lymphoma: long-term follow-up of 60 patients. J Clin Oncol 2014, 32:114-120

11. Laurent C, Delas A, Gaulard P, Haioun C, Moreau A, Xerri L, Traverse-Glehen A, Rousset T, Quintin-Roue I, Petrella T, Emile JF, Amara N, Rochaix P, Chenard-Neu MP, Tasei AM, Menet E, Chomarat H, Costes V, Andrac-Meyer L, Michiels JF, Chassagne-Clement C, de LL, Brousset P, Delsol G, Lamant L: Breast implant-associated anaplastic large cell lymphoma: two distinct clinicopathological variants with different outcomes. Ann Oncol 2016, 27:306-314

12. Blombery $\mathrm{P}$, Thompson ER, Jones $\mathrm{K}$, Arnau GM, Lade $\mathrm{S}$, Markham JF, Li J, Deva A, Johnstone RW, Khot A, Prince HM, Westerman D: Whole exome sequencing reveals activating JAK1 and STAT3 mutations in breast implant-associated anaplastic large cell lymphoma anaplastic large cell lymphoma. Haematologica 2016, 101:e387-e390

13. Santanelli di Pompeo F, Sorotos M: EURAPS editorial: BIA-ALCL, a brief overview. J Plast Reconstr Aesthet Surg 2018, 71:785-787

14. Flassbeck D, Pfleiderer B, Klemens P, Heumann KG, Eltze E, Hirner AV: Determination of siloxanes, silicon, and platinum in tissues of women with silicone gel-filled implants. Anal Bioanal Chem 2003, 375:356-362

15. Jacombs A, Tahir S, Hu H, Deva AK, Almatroudi A, Wessels WL, Bradshaw DA, Vickery K: In vitro and in vivo investigation of the influence of implant surface on the formation of bacterial biofilm in mammary implants. Plast Reconstr Surg 2014, 133:471e-480e

16. Linnemann T, Gellrich S, Lukowsky A, Mielke A, Audring H, Sterry W, Walden P: Polyclonal expansion of T cells with the TCR V beta type of the tumour cell in lesions of cutaneous T-cell lymphoma: evidence for possible superantigen involvement. Br J Dermatol 2004, 150:1013-1017

17. Di Napoli A, De Cecco L, Piccaluga PP, Navari M, Cancila V, Cippitelli C, Pepe G, Lopez G, Monardo F, Bianchi A, D’Amore ESG, Gianelli U, Facchetti F, Berti E, Bhagat G: Transcriptional analysis distinguishes breast implant-associated anaplastic large cell lymphoma from other peripheral T-cell lymphomas. Mod Pathol 2019, 32:216-230

18. Kang ST, Wang HC, Yang YT, Kou GH, Lo CF: The DNA virus white spot syndrome virus uses an internal ribosome entry site for translation of the highly expressed nonstructural protein ICP35. J Virol 2013, 87:13263-13278

19. Fitzal F, Turner SD, Kenner L: Is breast implant-associated anaplastic large cell lymphoma a hazard of breast implant surgery? Open Biol 2019, 9:190006

20. Kadin ME, Morgan J, Xu H, Epstein AL, Sieber D, Hubbard BA, Adams WP Jr, Bacchi CE, Goes JCS, Clemens MW, Medeiros LJ, Miranda RN: IL-13 is produced by tumor cells in breast implant associated anaplastic large cell lymphoma: implications for pathogenesis. Hum Pathol 2018, 78:54-62

21. Lechner MG, Megiel C, Church CH, Angell TE, Russell SM, Sevell RB, Jang JK, Brody GS, Epstein AL: Survival signals and targets for therapy in breast implant-associated ALK-anaplastic large cell lymphoma. Clin Cancer Res 2012, 18:4549-4559

22. Weiser JN, Nahm MH: Immunity to extracellular bacteria. Fundamental Immunology, ed 6. Edited by Paul WE. Philadelphia, PA: Lippincott Williams \& Wilkins, 2008. pp. 1182-1203

23. Medzhitov R: The innate immune system. Fundamental Immunology, ed 6. Edited by Paul WE. Philadelphia, PA: Lippincott Williams \& Wilkins, 2008. pp. 427-450

24. Aladily TN, Medeiros LJ, Amin MB, Haideri N, Ye D, Azevedo SJ, Jorgensen JL, de Peralta-Venturina M, Mustafa EB, Young KH, You MJ, Fayad LE, Blenc AM, Miranda RN: Anaplastic large cell lymphoma associated with breast implants: a report of 13 cases. Am J Surg Pathol 2012, 36:1000-1008

25. Quesada AE, Medeiros LJ, Clemens MW, Ferrufino-Schmidt MC, Pina-Oviedo S, Miranda RN: Breast implant-associated anaplastic large cell lymphoma: a review. Mod Pathol 2019, 32:166-168
26. Taylor CR, Siddiqi IN, Brody GS: Anaplastic large cell lymphoma occurring in association with breast implants: review of pathologic and immunohistochemical features in 103 cases. Appl Immunohistochem Mol Morphol 2013, 21:13-20

27. Di Napoli A, Pepe G, Giarnieri E, Cippitelli C, Bonifacino A, Mattei M, Martelli M, Falasca C, Cox MC, Santino I, Giovagnoli MR: Cytological diagnostic features of late breast implant seromas: from reactive to anaplastic large cell lymphoma. PLoS One 2017, 12:e0181097

28. Cappellano G, Ploner C, Lobenwein S, Sopper S, Hoertnagl P, Mayerl C, Wick N, Pierer G, Wick G, Wolfram D: Immunophenotypic characterization of human $\mathrm{T}$ cells after in vitro exposure to different silicone breast implant surfaces. PLoS One 2018, 13:e0192108

29. Hazenberg MD, Spits H: Human innate lymphoid cells. Blood 2014, 124:700-709

30. Miyagaki T, Sugaya M, Suga H, Kamata M, Ohmatsu H, Fujita H, Asano Y, Tada Y, Kadono T, Sato S: IL-22, but not IL-17, dominant environment in cutaneous T-cell lymphoma. Clin Cancer Res 2011, 17:7529-7538

31. Schleussner N, Merkel O, Costanza M, Liang HC, Hummel F, Romagnani C, Durek P, Anagnostopoulos I, Hummel M, Johrens K, Niedobitek A, Griffin PR, Piva R, Sczakiel HL, Woessmann W, Damm-Welk C, Hinze C, Stoiber D, Gillissen B, Turner SD, Kaergel E, von Hoff L, Grau M, Lenz G, Dorken B, Scheidereit C, Kenner L, Janz M, Mathas S: The AP-1-BATF and -BATF3 module is essential for growth, survival and TH17/ILC3 skewing of anaplastic large cell lymphoma. Leukemia 2018, 32:1994-2007

32. Montes-Mojarro IA, Steinhilber J, Bonzheim I, QuintanillaMartinez L, Fend F: The pathological spectrum of systemic anaplastic large cell lymphoma (ALCL). Cancers (Basel) 2018, 10:E107

33. Turner SD: An exploration into the origins and pathogenesis of anaplastic large cell lymphoma, anaplastic lymphoma kinase (ALK)positive. Cancers (Basel) 2017, 9:141

34. Stein H, Foss HD, Durkop H, Marafioti T, Delsol G, Pulford K, Pileri S, Falini B: CD30(+) anaplastic large cell lymphoma: a review of its histopathologic, genetic, and clinical features. Blood 2000, 96: $3681-3695$

35. Juco J, Holden JT, Mann KP, Kelley LG, Li S: Immunophenotypic analysis of anaplastic large cell lymphoma by flow cytometry. Am J Clin Pathol 2003, 119:205-212

36. van der Weyden CA, Pileri SA, Feldman AL, Whisstock J, Prince HM: Understanding CD30 biology and therapeutic targeting: a historical perspective providing insight into future directions. Blood Cancer J 2017, 7:e603

37. Bonzheim I, Geissinger E, Roth S, Zettl A, Marx A, Rosenwald A, Muller-Hermelink HK, Rudiger T: Anaplastic large cell lymphomas lack the expression of T-cell receptor molecules or molecules of proximal T-cell receptor signaling. Blood 2004, 104:3358-3360

38. Geissinger E, Sadler P, Roth S, Grieb T, Puppe B, Muller N, Reimer P, Vetter-Kauczok CS, Wenzel J, Bonzheim I, Rudiger T, Muller-Hermelink HK, Rosenwald A: Disturbed expression of the T-cell receptor/CD3 complex and associated signaling molecules in CD30+ T-cell lymphoproliferations. Haematologica 2010, 95: $1697-1704$

39. Malcolm TI, Villarese P, Fairbairn CJ, Lamant L, Trinquand A, Hook CE, Burke GA, Brugieres L, Hughes K, Payet D, Merkel O, Schiefer AI, Ashankyty I, Mian S, Wasik M, Turner M, Kenner L, Asnafi V, Macintyre E, Turner SD: Anaplastic large cell lymphoma arises in thymocytes and requires transient TCR expression for thymic egress. Nat Commun 2016, 7:10087

40. Stein H, Mason DY, Gerdes J, O'Connor N, Wainscoat J, Pallesen G, Gatter K, Falini B, Delsol G, Lemke H, Schwarting R, Lennert K: The expression of the Hodgkin's disease associated antigen Ki-1 in reactive and neoplastic lymphoid tissue: evidence that ReedSternberg cells and histiocytic malignancies are derived from activated lymphoid cells. Blood 1985, 66:848-858 
41. Kesler MV, Paranjape GS, Asplund SL, McKenna RW, Jamal S, Kroft SH: Anaplastic large cell lymphoma: a flow cytometric analysis of 29 cases. Am J Clin Pathol 2007, 128:314-322

42. Massone C, Cerroni L: Phenotypic variability in primary cutaneous anaplastic large T-cell lymphoma: a study on 35 patients. Am J Dermatopathol 2014, 36:153-157

43. Krenacs L, Wellmann A, Sorbara L, Himmelmann AW, Bagdi E, Jaffe ES, Raffeld M: Cytotoxic cell antigen expression in anaplastic large cell lymphomas of T- and null-cell type and Hodgkin's disease: evidence for distinct cellular origin. Blood 1997, 89:980-989

44. Kumura T, Hino M, Yamane T, Ohta K, Nakao T, Wakasa K, Tatsumi N: Triple-negative (CD3-/CD4-/CD8-) adult T cell leukemia/lymphoma, histologically presenting as CD30 (Ki-1)-positive anaplastic large cell lymphoma with clonal Epstein-Barr virus genome. Leukemia 2001, 15:994-995

45. Foss HD, Anagnostopoulos I, Araujo I, Assaf C, Demel G, Kummer JA, Hummel M, Stein H: Anaplastic large-cell lymphomas of T-cell and null-cell phenotype express cytotoxic molecules. Blood 1996, 88:4005-4011

46. de Jong D, Vasmel WL, de Boer JP, Verhave G, Barbe E, Casparie MK, van Leeuwen FE: Anaplastic large-cell lymphoma in women with breast implants. JAMA 2008, 300:2030-2035

47. Plaza JA, Feldman AL, Magro C: Cutaneous CD30-positive lymphoproliferative disorders with CD8 expression: a clinicopathologic study of 21 cases. J Cutan Pathol 2013, 40:236-247

48. Kadin ME, Deva A, Xu H, Morgan J, Khare P, MacLeod RA, Van Natta BW, Adams WP Jr, Brody GS, Epstein AL: Biomarkers provide clues to early events in the pathogenesis of breast implant-associated anaplastic large cell lymphoma. Aesthet Surg J 2016, 36:773-781

49. Moti N, Malcolm T, Hamoudi R, Mian S, Garland G, Hook CE, Burke GA, Wasik MA, Merkel O, Kenner L, Laurenti E, Dick JE, Turner SD: Anaplastic large cell lymphoma-propagating cells are detectable by side population analysis and possess an expression profile reflective of a primitive origin. Oncogene 2015, 34: $1843-1852$

50. Eckerle S, Brune V, Doring C, Tiacci E, Bohle V, Sundstrom C, Kodet R, Paulli M, Falini B, Klapper W, Chaubert AB, Willenbrock K, Metzler D, Brauninger A, Kuppers R, Hansmann ML: Gene expression profiling of isolated tumour cells from anaplastic large cell lymphomas: insights into its cellular origin, pathogenesis and relation to Hodgkin lymphoma. Leukemia 2009, 23: 2129-2138

51. Hassler MR, Pulverer W, Lakshminarasimhan R, Redl E, Hacker J, Garland GD, Merkel O, Schiefer AI, Simonitsch-Klupp I, Kenner L, Weisenberger DJ, Weinhaeusel A, Turner SD, Egger G: Insights into the pathogenesis of anaplastic large-cell lymphoma through genomewide DNA methylation profiling. Cell Rep 2016, 17:596-608

52. Iqbal J, Weisenburger DD, Greiner TC, Vose JM, McKeithan T, Kucuk C, Geng H, Deffenbacher K, Smith L, Dybkaer K, Nakamura S, Seto M, Delabie J, Berger F, Loong F, Au WY, Ko YH, Sng I, Armitage JO, Chan WC: Molecular signatures to improve diagnosis in peripheral T-cell lymphoma and prognostication in angioimmunoblastic T-cell lymphoma. Blood 2010, 115:1026-1036

53. Malcolm TI, Hodson DJ, Macintyre EA, Turner SD: Challenging perspectives on the cellular origins of lymphoma. Open Biol 2016, 6:160232

54. O'Shea JJ, Paul WE: Mechanisms underlying lineage commitment and plasticity of helper CD4+ T cells. Science 2010, 327:1098-1102

55. Muranski P, Restifo NP: Essentials of Th17 cell commitment and plasticity. Blood 2013, 121:2402-2414

56. Guery L, Hugues S: Th17 cell plasticity and functions in cancer immunity. Biomed Res Int 2015, 2015:314620

57. Cho-Vega JH, Rassidakis GZ, Amin HM, Tsioli P, Spurgers K, Remache YK, Vega F, Goy AH, Gilles F, Medeiros LJ: Suppressor of cytokine signaling 3 expression in anaplastic large cell lymphoma. Leukemia 2004, 18:1872-1878
58. Laimer D, Dolznig H, Kollmann K, Vesely PW, Schlederer M, Merkel O, et al: PDGFR blockade is a rational and effective therapy for NPM-ALK-driven lymphomas. Nat Med 2012, 18:1699-1704

59. Schiefer AI, Vesely P, Hassler MR, Egger G, Kenner L: The role of AP-1 and epigenetics in ALCL. Front Biosci (Schol Ed) 2015, 7: 226-235

60. Vassallo J, Lamant L, Brugieres L, Gaillard F, Campo E, Brousset P, Delsol G: ALK-positive anaplastic large cell lymphoma mimicking nodular sclerosis Hodgkin's lymphoma: report of 10 cases. Am J Surg Pathol 2006, 30:223-229

61. Savan R, McFarland AP, Reynolds DA, Feigenbaum L, Ramakrishnan K, Karwan M, Shirota H, Klinman DM, Dunleavy K, Pittaluga S, Anderson SK, Donnelly RP, Wilson WH, Young HA: A novel role for IL-22R1 as a driver of inflammation. Blood 2011, 117: $575-584$

62. Chen CY, Lee JB, Liu B, Ohta S, Wang PY, Kartashov AV, Mugge L, Abonia JP, Barski A, Izuhara K, Rothenberg ME, Finkelman FD, Hogan SP, Wang YH: Induction of interleukin-9producing mucosal mast cells promotes susceptibility to IgEmediated experimental food allergy. Immunity 2015, 43:788-802

63. Burd PR, Thompson WC, Max EE, Mills FC: Activated mast cells produce interleukin 13. J Exp Med 1995, 181:1373-1380

64. Galli SJ, Tsai M: IgE and mast cells in allergic disease. Nat Med 2012, 18:693-704

65. Kadin ME, Morgan J, Xu H, Epstein A, Miranda RN, Sieber D, Clemens MW: Breast implant associated ALCL tumor expresses prostaglandin D2 receptor: an allergic inflammation pathogenesis. Annual Meeting of the American Association of Plastic Surgeons [abstract 34], April 7-10, 2018, Seattle, WA. Arlington Heights, IL, American Association of Plastic Surgeons, 2018

66. Pinto A, Aldinucci D, Gloghini A, Zagonel V, Degan M, Improta S, Juzbasic S, Todesco M, Perin V, Gattei V, Herrmann F, Gruss HJ, Carbone A: Human eosinophils express functional CD30 ligand and stimulate proliferation of a Hodgkin's disease cell line. Blood 1996, 88:3299-3305

67. von Wasielewski R, Seth S, Franklin J, Fischer R, Hubner K, Hansmann ML, Diehl V, Georgii A: Tissue eosinophilia correlates strongly with poor prognosis in nodular sclerosing Hodgkin's disease, allowing for known prognostic factors. Blood 2000, 95:1207-1213

68. Gattei V, Degan M, Gloghini A, De Iuliis A, Improta S, Rossi FM, Aldinucci D, Perin V, Serraino D, Babare R, Zagonel V, Gruss HJ, Carbone A, Pinto A: CD30 ligand is frequently expressed in human hematopoietic malignancies of myeloid and lymphoid origin. Blood 1997, 89:2048-2059

69. Xu L, Kitani A, Fuss I, Strober W: Cutting edge: regulatory T cells induce $\mathrm{CD} 4+\mathrm{CD} 25$-Foxp3- $\mathrm{T}$ cells or are self-induced to become Th17 cells in the absence of exogenous TGF-beta. J Immunol 2007, 178:6725-6729

70. Harlin H, Podack E, Boothby M, Alegre ML: TCR-independent CD30 signaling selectively induces IL-13 production via a TNF receptor-associated factor/p38 mitogen-activated protein kinasedependent mechanism. J Immunol 2002, 169:2451-2459

71. Jatiani SS, Baker SJ, Silverman LR, Reddy EP: Jak/STAT pathways in cytokine signaling and myeloproliferative disorders: approaches for targeted therapies. Genes Cancer 2010, 1:979-993

72. Elenitoba-Johnson KSJ, Lim MS: New insights into lymphoma pathogenesis. Annu Rev Pathol 2018, 13:193-217

73. Pizzi M, Margolskee E, Inghirami G: Pathogenesis of peripheral T cell lymphoma. Annu Rev Pathol 2018, 13:293-320

74. Prutsch N, Gurnhofer E, Suske T, Liang HC, Schlederer M, Roos S, Wu LC, Simonitsch-Klupp I, Alvarez-Hernandez A, Kornauth C, Leone DA, Svinka J, Eferl R, Limberger T, Aufinger A, Shirsath N, Wolf P, Hielscher T, Aberger F, Schmoellerl J, Stoiber D, Strobl B, Jager U, Staber PB, Grebien F, Moriggl R, Muller M, Inghirami GG, Sanda T, Look AT, Turner SD, Kenner L, Merkel O: Dependency on the TYK2/STAT1/MCL1 axis in anaplastic large cell lymphoma. Leukemia 2019, 33:696-709 
75. Crescenzo R, Abate F, Lasorsa E, Tabbo F, Gaudiano M, Chiesa N, et al: Convergent mutations and kinase fusions lead to oncogenic STAT3 activation in anaplastic large cell lymphoma. Cancer Cell 2015, 27:516-532

76. Oishi N, Brody GS, Ketterling RP, Viswanatha DS, He R, Dasari S, Mai M, Benson HK, Sattler CA, Boddicker RL, McPhail ED, Bennani NN, Harless CA, Singh K, Clemens MW, Medeiros LJ, Miranda RN, Feldman AL: Genetic subtyping of breast implantassociated anaplastic large cell lymphoma. Blood 2018, 132:544-547

77. Hodge DR, Hurt EM, Farrar WL: The role of IL-6 and STAT3 in inflammation and cancer. Eur J Cancer 2005, 41:2502-2512

78. Hutchins AP, Diez D, Miranda-Saavedra D: The IL-10/STAT3mediated anti-inflammatory response: recent developments and future challenges. Brief Funct Genomics 2013, 12:489-498

79. Chen J, Zhang Y, Petrus MN, Xiao W, Nicolae A, Raffeld M, Pittaluga S, Bamford RN, Nakagawa M, Ouyang ST, Epstein AL,
Kadin ME, Del Mistro A, Woessner R, Jaffe ES, Waldmann TA: Cytokine receptor signaling is required for the survival of ALKanaplastic large cell lymphoma, even in the presence of JAK1/STAT3 mutations. Proc Natl Acad Sci U S A 2017, 114:3975-3980

80. Alderuccio JP, Desai A, Yepes MM, Chapman JR, Vega F, Lossos IS: Frontline brentuximab vedotin in breast implantassociated anaplastic large-cell lymphoma. Clin Case Rep 2018 , 6:634-637

81. Johnson L, O'Donoghue JM, McLean N, Turton P, Khan AA, Turner SD, Lennard A, Collis N, Butterworth M, Gui G, Bristol J, Hurren J, Smith S, Grover K, Spyrou G, Krupa K, Azmy IA, Young IE, Staiano JJ, Khalil H, MacNeill FA: Breast implant associated anaplastic large cell lymphoma: the UK experience: recommendations on its management and implications for informed consent. Eur J Surg Oncol 2017, 43:1393-1401 